\title{
The Association Between COVID-19 Incidence and Mortality with Socioeconomic Development - A Global Ecological Study
}

\section{Samaneh Torkian}

Iran University of Medical Sciences: Tehran University of Medical Sciences

\section{Samira Kazemi}

iran university of medical science

\section{Marzieh Eslahi}

kerman university of medical science

\section{Elham Khatooni}

Tehran University: University of Tehran

\section{Reza Etesami}

shahid bahonar university

Narges Khanjani ( $\boldsymbol{Q}$ n_khanjani@kmu.ac.ir)

Kerman University of Medical Sciences

\section{Roya Rashti}

Kurdistan University of Medical Science: Kurdistan University of Medical Sciences

\section{Research article}

Keywords: COVID-19, Socioeconomic Development, HDI, IHDI, GII, GDI, Gini Index

Posted Date: December 3rd, 2020

DOl: https://doi.org/10.21203/rs.3.rs-117325/v1

License: (c) (i) This work is licensed under a Creative Commons Attribution 4.0 International License. Read Full License 


\section{Abstract}

Background: There is some evidence about the role of human development in the incidence and mortality of some diseases. The aim of this study was to investigate the relation between COVID-19 incidence and mortality with development indexes in different regions of the world.

Methods: This ecological study was conducted on data from January 11 to August 23, 2020. The development indexes included were Human development index (HDI), Inequality-adjusted HDI (IHDI), the Gini Coefficient, Gender Development Index (GDI), Gender Inequality Index (GII) and their components. The development indexes was obtained from the United Nations Development Program (UNDP). COVID19 cases and mortality data of the countries involved in the pandemic were obtained from the European Centre for Disease Prevention and Control (ECDC). Data was analyzed by Spearman correlation coefficients and negative binomial regression through SPSS26.

Results: The highest and lowest incidence and mortality rates were in the AMRO and WPRO regions, respectively. The development indexes had no a significant linear correlation with COVID-19 incidence and mortality except in WPRO, where there was direct significant correlation between life expectancy at birth and inequality adjusted life expectancy with COVID-19 incidence and mortality $(P<0.05)$.

Conclusions: Our findings suggests limited evidence that countries level of development may directly influence morbidity and mortality from COVID-19. However, with regard to the ecological nature of this study, the reason for this association is difficult to determine.

\section{Background}

A novel coronavirus, named coronavirus disease 2019 (COVID-19), was identified as the cause of a cluster of pneumonia cases in Wuhan, a city in the Hubei province of China, at the end of 2019. On January 30, 2020, the World Health Organization (WHO) declared the outbreak a "Public Health Emergency of International Concern" (PHEIC) (1) and on 11, March 2020 WHO announced COVID-19 as a pandemic (2). Based on the WHO statistics 25327098 confirmed cases and 848255 deaths happened in 216 countries, areas or territories up to 1 September 2020 (3). Hauser et al indicated that the expected burden of this disease for populations will increase with further expansion of the COVID-19 epidemic around the globe (4).

There is evidence about the role of human development in incidence and mortality of some diseases (57). Traditionally and before the first human development report of the United Nations Development Program (UNDP) in 1990, "development " had been defined, measured and expressed in economic terms. In fact, societies with strong economic background were considered highly developed and vise-versa (8). However, comparison of societies' development level based on only economic indicators may lead to unrealistic and unreliable results. In fact, economic indicators alone could not properly reflect the performance of countries in the other areas such as environment, public health, public education and etc (8). In 1990, the UNDP introduced a new concept of development which in addition to economic 
indicators, consisted of health and education indicators and was called the Human Development Index (HDI) (9). In fact, the HDI was created to indicate that the people, and their capabilities should be the ultimate criteria for assessing the development of a country, not economic growth alone (10).

In 1995, the Gender Related Development Index (GDI) was introduced in the Human Development Report written by the UNDP. The aim of this index was to add a gender-sensitive dimension to the Human Development Index (HDI) and measure gender equality (11). The Gender Inequality Index (GII) is an index for measurement of gender disparity that was introduced in the 2010 Human Development Report's 20th anniversary edition by the UNDP. According to the UNDP, this index is a composite measure used to quantify the loss of achievement within a country due to gender inequality. The new index was introduced as an experimental measure to remedy the shortcomings of the previous indicators, GDI and the Gender Empowerment Measure (GEM), both of which were introduced in the 1995 Human Development Report (12).

The 2010 Human Development Report introduced an Inequality-adjusted Human Development Index (IHDI). While the simple HDI remains useful, it is stated that "the IHDI is the actual level of human development (accounting for inequality)", and "the HDI can be viewed as an index of potential human development or the maximum IHDI that could be achieved if there were no inequality" $(13,14)$.

The oldest development index is the Gini coefficient which was developed by the Italian statistician, Corrado Gini in 1912. Gini proposed that the difference between the hypothetical straight line depicting perfect equality, and the actual line depicting people's incomes, can be used as a measure of inequality. Gini index varies between 0 , which shows perfect equitability where everyone has the same share of the good, and 1, where one person has everything (15).

There is no evidence about the role of social development in the control of COVID-19. This study was conducted to investigate COVID- 19 incidence and mortality in different regions of the world in relation to countries' level of development. COVID-19 has caused a considerable burden in the world, and evaluating the different incidence and mortality rates of the disease and its related factors may lead us to better understand the nature and trend of this disease.

\section{Methods}

This was an ecological study about the relation between COVID-19 incidence and mortality with the Human development index (HDI), Inequality-adjusted HDI (IHDI), Gini Coefficient, Gender Development Index (GDI), Gender Inequality Index (GII) and their components, conducted on data from January 11 to August 23, 2020.

HDI has three dimensions that include: life expectancy, education, and gross national income (GNI). Inequality - adjusted life expectancy, inequality - adjusted education and inequality - adjusted income indexes are the dimensions of IHDI. GDI has two components that include female and male HDI. 
The development data of all world countries were not available. HDI was available for 173 , IHDI and Gini Index for 144 , and GDI and GII for 126 countries.

COVID-19 incidence and mortality data and development indicators were obtained from the European Centre for Disease Prevention and Control (ECDC) and United Nations Development Program (UNDP). Until August 23, 216 countries were affected by the COVID-19.

We analyzed the available data in the six WHO regions. These regions included the African Region (AFRO), Region of the Americas (AMRO), Eastern Mediterranean Region (EMRO), European Region (EURO), South-East Asia Region (SEARO) and Western Pacific Region (WPRO).

Spearman correlation coefficient were calculated and Negative Binomial (NB) regression models were used to examine the effect of HD indices on COVID 19 incidence and mortality. In NB regression, due to the large number of cases and deaths (response variable) and the small value of development indicators (independent variables), development indicators were multiplied by 100 to facilitate RR interpretation. Spearman correlation coefficient ( $r$ ), Risk Ratios (RR) and p-values were reported. We considered a pvalue $<0.05$ as the level of statistical significance. SPSS version 26 and Stata version 14 were used to analyze the data.

\section{Results}

In total 22945248 new cases and 800003 deaths due to COVID-19 were recorded worldwide until August 23, 2020. The number of cases and deaths in the AMRO region was 12326081 and 439406 , in EURO 3955045 and 217 765, in AFRO 987990 and 20 069, in WPRO 444123 and 9 517, in SEARO 3459 461 and 66 392, in AMRO 1772548 and 47 854. The highest and lowest number of cases and death due to COVID-19 were in the AMRO and WPRO regions, respectively.

The results of Spearman correlation showed that in WPRO, there was a significant direct correlation between life expectancy at birth and inequality adjusted life expectancy with COVID-19 incidence and mortality (Table 1, A-F).

Increase in the HDI index was associated with an increased incidence in AMRO and AFRO areas and with an increased mortality in AMRO, EURO and AFRO.

The results for life expectancy at birth were inconsistent. Increase in life expectancy at birth index was associated with an increased incidence in AMRO area and an increased mortality in EURO, but a decreased incidence in SEARO.

Increase in the expected years of schooling index was associated with an increased incidence in EURO and AFRO and an increased mortality in AMRO, EURO and AFRO.

Increase in the mean years of schooling index was associated with an increased incidence in AFRO and an increased mortality in AMRO and AFRO. 
The results for GNI were inconsistent. Increase in the GNI index was associated with an increased incidence in AFRO and an increased mortality in WPRO, but a decreased incidence in EURO and SEARO (Table 1, A-F).

Increase in the IHDI index was associated with an increased incidence in AMRO and AFRO and an increase mortality in WURO and AFRO.

The results for inequality adjusted life expectancy index were inconsistent. Increase in the inequality adjusted life expectancy index was associated with an increased incidence in AMRO and AFRO areas, an increased mortality in EURO and AFRO, but a decrease in both mortality and incidence in SEARO.

Increase in the inequality adjusted education index was associated with an increased incidence in AMRO and AFRO and an increased mortality in AFRO.

Increase in the inequality adjusted income index was associated with an increased incidence in EMRO and an increased mortality in EURO and EMRO (Table 1, A-F).

The results for GDI were inconsistent. Increase in GDI was associated with an increased incidence in WPRO but a decreased mortality in SEARO and EMRO.

The results for GII were inconsistent. Increase in the GII index was associated with an increased incidence in SEARO, and increased mortality in SEARO and EMRO, but a decreased incidence in AFRO and a decreased mortality in EURO.

Increase in male-HDI index was associated with an increased incidence in AMRO, EURO, AFRO and EMRO, as well as an increased mortality in AMRO, EURO and AFRO. But, the results for GIl were inconsistent. Increase in female-HDI was associated with an increased incidence in AMRO and AFRO, and an increased mortality in AMRO, EURO and AFRO, but a decreased incidence in SEARO.

Increase in the Gini index was associated with an increased incidence and mortality in EURO and AFRO (Table 1, A-F).

\section{Discussion}

Past research has shown that public health outcomes are influenced by indicators of human development, such as education, employment, and income, probably because these variables impact access to public health infrastructure and general health of populations (16). Some researchers even believe that the COVID-19 epidemic around the world could have been estimated and mapped out to some degree of accuracy by simply taking into account some macro variables, such as the population size, HDI scores, and immigrant stock from the origin, at each destination (17).

In 14 regions of Asia, a moderate positive correlation was found between confirmed and deceased cases of COVID-19 with HDI (18). In inner São Paulo state municipalities, with a 10\% increase in the Gini and 
HDI index, the confirmed COVID-19 cases significantly increase 1.32 and 0.54 times, respectively (19) and with a 10\% increase in Gini and HDI index, COVID-19 mortality increased significantly 0.6 times and insignificantly 1.42 times, respectively (19).

The incidence of COVID-19 was reported to have spatial dependence with moderate positive correlation with MHDI (municipal human development index) in the state of Ceará in Brazil (20). Another ecological study showed a significant positive correlation between the incidence of COVID-2019 and HDI around the world (21). In the present study, in developed regions including the United States and Europe, the HDI index was associated with an increase in cases.

Inequality in human development affects countries' capacity to respond to COVID-19. (22). The availability of resources is intertwined with the ability to react to a crisis and includes the ability to monitor the crisis for decision making, ability to treat those requiring medical attention and ability to develop new products and services to adapt to the changing circumstances in the health system and beyond (23).

Crises have multiple interconnected health, economic and social dimensions (23). GDP and HDI may creat better public health infrastructure that affects the health of citizens in every country of the world, regardless of their listed UN or World Bank wealth status (22).

The public health policies to slow the spread of COVID-19 are premised on reducing human interaction and as a result will slow down economic activity (23). The response to COVID-19 has to balance public health priorities with economic and social activities, accommodating short-term measures to mitigate the spread of the virus and their long-term effects. A human development approach places protecting and enhancing human capabilities as the central anchor, guiding analysis and policy, with a systemic and long-term view. Countries and communities that can deal with COVID 19 through non-pharmaceutical interventions are expected to be better in the long run; but in short term, these interventions, can damage the economy or activities for which social distancing is difficult or impossible (23).

To the best of our knowledge, our study is the first to investigate the relation between several different socioeconomic indexes and COVID-19 incidence and mortality. One of the limitations of this study was the lack of development indicators for all countries involved in the COVID-19 pandemic.

\section{Conclusion}

Some socioeconomic indexes were directly associated with increased COVID-19 incidence and mortality around the world. Results of the present study can help policy makers and health officials determine the most vulnerable areas and plan to make socioeconomic improvements that can consequently enhance people's health.

The proposal of this research has been approved by Kerman University of Medical Sciences with the code of ethics IR.KMU.REC.1399.402. 


\section{Declarations}

Ethics approval and consent to participate: Ethics approval was obtained from the Kerman University of Medical Sciences with the ethical code IR.KMU.REC.1399.402.

\section{Consent for publication:}

Not applicable.

\section{Availability of data and materials:}

The data that support the findings of this study are available from the corresponding author, [N.K.], upon reasonable request.

\section{Competing interests:}

The Authors declare that there is no conflict of interest.

\section{Funding:}

Kerman University of Medical Science financially supported this work through Grant No 99000359.

Authors' contributions: S.T., M.E., E.K., N.K., R.R and S.K. wrote the first draft, and the statistical analysis was conducted by R.E. and S.T. All authors contributed to the data collection, interpreting the results and commenting on the initial manuscripts.

\section{Acknowledgments}

We would like to acknowledge Kerman University of Medical Sciences for financially supporting this project.

ORCID:

Narges Khanjani, https://orcid.org/0000-0002-7235-9253

\section{References}

1. Team EE. Note from the editors: World Health Organization declares novel coronavirus (2019-nCoV) sixth public health emergency of international concern. Eurosurveillance. 2020;25(5):200131e.

2. Galib BA. SARS-CoV-2 (COVID-19). Journal of the Faculty of Medicine Baghdad. 2019;61(3):4.

3. Wu Z, McGoogan JM. Characteristics of and important lessons from the coronavirus disease 2019 (COVID-19) outbreak in China: summary of a report of 72314 cases from the Chinese Center for Disease Control and Prevention. Jama. 2020;323(13):1239-42.

4. Hauser A, Counotte MJ, Margossian CC, Konstantinoudis G, Low N, Althaus CL, et al. 2020. 
5. Fidler MM, Soerjomataram I, Bray F. A global view on cancer incidence and national levels of the human development index. International journal of cancer. 2016;139(11):2436-46.

6. Zhu K-F, Wang Y-M, Zhu J-Z, Zhou Q-Y, Wang N-F. National prevalence of coronary heart disease and its relationship with human development index: a systematic review. European journal of preventive cardiology. 2016;23(5):530-43.

7. Hu Q-D, Zhang Q, Chen W, Bai X-L, Liang T-B. Human development index is associated with mortalityto-incidence ratios of gastrointestinal cancers. World journal of gastroenterology: WJG. 2013;19(32):5261.

8. Bilbao-Ubillos J. Another approach to measuring human development: The composite dynamic Human Development Index. Soc Indic Res. 2013;111(2):473-84.

9. You Z, Shi H, Feng Z, Yang Y. Creation and validation of a socioeconomic development index: A case study on the countries in the Belt and Road Initiative. J Clean Prod. 2020;258:120634.

10. Omrani H, Alizadeh A, Amini M. A new approach based on BWM and MULTIMOORA methods for calculating semi-human development index: An application for provinces of Iran. Socio-Economic Planning Sciences. 2020;70:100689.

11. Klasen S. UNDP's gender-related measures: some conceptual problems and possible solutions. Journal of Human Development. 2006;7(2):243-74.

12. Ferrant G. The Gender Inequalities Index (GII) as a New Way to Understand Gender Inequality Issues in Developing Countries. 2010.

13. Martínez R. Inequality and the new human development index. Appl Econ Lett. 2012;19(6):533-5.

14. Fidler MM, Bray F. Global cancer inequalities. Frontiers in oncology. 2018;8:293.

15. Ceriani L, Verme P. The origins of the Gini index: extracts from Variabilità e Mutabilità (1912) by Corrado Gini. The Journal of Economic Inequality. 2012;10(3):421-43.

16. Leung TY, Sharma P, Adithipyangkul P, Hosie P. Gender equity and public health outcomes: The COVID-19 experience. Journal of Business Research. 2020.

17. Sirkeci I, Yucesahin MM. Coronavirus and Migration: Analysis of Human Mobility and the Spread of COVID-19. Migration Letters. 2020;17(2):379-98.

18. Hernández-Aguilar C, Pacheco FD. Relationship of airports, population, competitiveness indexes and human development with confirmed and deceased cases by COVID-19: Need for transdisciplinary systemic decisions. Transdisciplinary Journal of Engineering \& Science. 2020;11.

19. Fortaleza CMCB, Guimarães RB, de Almeida GB, Pronunciate M, Ferreira CP. Taking the inner route: spatial and demographic factors affecting vulnerability to COVID-19 among 604 cities from inner São Paulo State, Brazil. Epidemiology \& Infection. 2020;148.

20. Maciel JAC, Castro-Silva II, Farias MRd. Initial analysis of the spatial correlation between the incidence of COVID-19 and human development in the municipalities of the state of Ceará in Brazil. Revista Brasileira de Epidemiologia. 2020;23:e200057. 
21. Khazaei Z, Mazaheri E, Hasanpour-Dehkordi A, Rahimi Pordanjani S, Naghibzadeh-Tahami A, Naemi $\mathrm{H}$, et al. COVID-19 Pandemic in the World and its Relation to Human Development Index: A Global Study. Archives of Clinical Infectious Diseases. (In Press).

22. Freed JS, Kwon SY, El HJ, Gottlieb M, Roth R. Which Country is Truly Developed? COVID-19 has Answered the Question. Annals of global health. 2020;86(1).

23. Programme UND. COVID-19 AND HUMAN DEVELOPMENT:Assessing the Crisis, Envisioning the Recovery. 2020.

\section{Tables}


Table 1-A. Association of COVID-19 incidence and mortality with development indices in the American region

\begin{tabular}{|c|c|c|c|c|c|c|c|c|}
\hline \multirow[t]{2}{*}{ Variables } & \multicolumn{4}{|c|}{ Confirmed Case } & \multicolumn{4}{|c|}{ Confirmed Deaths } \\
\hline & $\begin{array}{l}\text { RR } \\
\text { (95\% } \\
\text { Cl) }\end{array}$ & $\begin{array}{l}\mathrm{P}- \\
\text { value }\end{array}$ & $r_{s}$ & $\begin{array}{l}\mathrm{P}- \\
\text { value }\end{array}$ & $\begin{array}{l}\text { RR } \\
\text { (95\% } \\
\text { Cl) }\end{array}$ & $\begin{array}{l}\mathrm{P} \text { - } \\
\text { value }\end{array}$ & $r_{s}$ & $\begin{array}{l}\mathrm{P}- \\
\text { value }\end{array}$ \\
\hline
\end{tabular}

AMRO

$\mathrm{HDI}(\mathrm{n}=33)$

$1.14<0.001$

0.162

0.368

1.15

$(1.09-$

$<0.001$

0.163

0.363

1.19)

1.21)

Life expectancy at

birth $(n=34)$

$\begin{array}{llll}1.00 & <0.001 & 0.204 & 0.247\end{array}$

(1.00-

0.99

(0.98-

0.703

1.01)

\begin{tabular}{|c|c|c|c|c|c|c|c|}
\hline $\begin{array}{l}\text { Expected years of } \\
\text { schooling }(\mathrm{n}=34)\end{array}$ & $\begin{array}{l}0.99 \\
(0.97- \\
1.01)\end{array}$ & 0.511 & 0.283 & 0.105 & $\begin{array}{l}1.02 \\
(1.00- \\
1.03)\end{array}$ & 0.010 & 0.265 \\
\hline
\end{tabular}

\begin{tabular}{|c|c|c|c|c|c|c|c|}
\hline $\begin{array}{l}\text { Mean years of } \\
\text { schooling }(n=33)\end{array}$ & $\begin{array}{l}1.00 \\
(0.99- \\
1.00)\end{array}$ & 0.112 & 0.098 & 0.589 & $\begin{array}{l}1.04 \\
(1.00- \\
1.08)\end{array}$ & 0.020 & 0.059 \\
\hline
\end{tabular}

\begin{tabular}{|c|c|c|c|c|c|c|c|c|}
\hline GNI(n=33) & $\begin{array}{l}1.00 \\
(0.99- \\
1.00)\end{array}$ & 0.077 & 0.163 & 0.364 & $\begin{array}{l}1.00 \\
(0.99- \\
1.00)\end{array}$ & 0.153 & 0.148 & 0.411 \\
\hline IHDI(n=26) & $\begin{array}{l}1.38 \\
(1.07- \\
1.78)\end{array}$ & 0.011 & 0.237 & 0.244 & $\begin{array}{l}1.21 \\
(0.72- \\
2.07)\end{array}$ & 0.469 & 0.212 & 0.298 \\
\hline
\end{tabular}

\begin{tabular}{|c|c|c|c|c|c|c|c|}
\hline $\begin{array}{l}\text { Inequality adjusted life } \\
\text { expectancy } \\
\text { index(n=33) }\end{array}$ & $\begin{array}{l}1.14 \\
(1.09- \\
1.18)\end{array}$ & $<0.001$ & 0.228 & 0.201 & $\begin{array}{l}0.92 \\
(0.54- \\
1.55)\end{array}$ & 0.758 & 0.238 \\
\hline
\end{tabular}

\begin{tabular}{|c|c|c|c|c|c|c|c|}
\hline $\begin{array}{l}\text { Inequality adjusted } \\
\text { education index }(n=29)\end{array}$ & $\begin{array}{l}1.05 \\
(1.02- \\
1.08)\end{array}$ & 0.001 & 0.030 & 0.879 & $\begin{array}{l}1.46 \\
(0.57- \\
3.78)\end{array}$ & 0.426 & -0.002 \\
\hline
\end{tabular}

\begin{tabular}{|c|c|c|c|c|c|c|c|}
\hline $\begin{array}{l}\text { Inequality adjusted } \\
\text { income index }(n=27)\end{array}$ & $\begin{array}{l}1.24 \\
(0.78- \\
1.98)\end{array}$ & 0.346 & 0.329 & 0.094 & $\begin{array}{l}1.11 \\
(0.40- \\
3.11)\end{array}$ & 0.833 & 0.301 \\
\hline
\end{tabular}

\begin{tabular}{|c|c|c|c|c|c|c|c|c|}
\hline GDI(n=28) & $\begin{array}{l}1.26 \\
(0.84- \\
1.89)\end{array}$ & 0.262 & -0.163 & 0.408 & $\begin{array}{l}1.07 \\
(0.68- \\
1.69)\end{array}$ & 0.741 & -0.203 & 0.301 \\
\hline$G \|(n=29)$ & $\begin{array}{l}0.35 \\
(0.07- \\
1.64)\end{array}$ & 0.185 & -0.067 & 0.728 & $\begin{array}{l}0.89 \\
(0.81- \\
1.01)\end{array}$ & 0.059 & -0.069 & 0.722 \\
\hline HDI- Male(n=29) & $\begin{array}{l}1.16 \\
\text { (1.11- }\end{array}$ & $<0.001$ & 0.294 & 0.121 & $\begin{array}{l}1.48 \\
(1.08-\end{array}$ & 0.040 & 0.285 & 0.134 \\
\hline
\end{tabular}




\begin{tabular}{|c|c|c|c|c|c|c|c|c|}
\hline & $1.22)$ & & & & 2.03) & & & \\
\hline HDI- Female $(n=30)$ & $\begin{array}{l}1.14 \\
(1.10- \\
1.19)\end{array}$ & $<0.001$ & 0.242 & 0.197 & $\begin{array}{l}1.52 \\
(1.17- \\
1.98)\end{array}$ & 0.002 & 0.229 & 0.224 \\
\hline Gini Coefficient( $n=21)$ & $\begin{array}{l}1.00 \\
(0.99- \\
1.00)\end{array}$ & 0.637 & -0.066 & 0.775 & $\begin{array}{l}1.00 \\
(0.99- \\
1.00)\end{array}$ & 0.851 & -0.079 & 0.735 \\
\hline
\end{tabular}


Table 1-B. Association of COVID-19 incidence and mortality with development indices in the European region

Variables

Confirmed Case

Confirmed Deaths

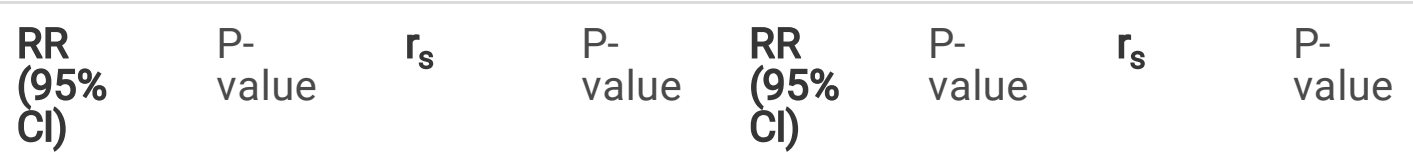

EURO

\begin{tabular}{|c|c|c|c|c|c|c|c|c|}
\hline $\mathrm{HDI}(\mathrm{n}=51)$ & $\begin{array}{l}1.02 \\
(0.97- \\
1.06)\end{array}$ & 0.395 & 0.008 & 0.995 & $\begin{array}{l}1.11 \\
(1.06- \\
1.15)\end{array}$ & $<0.001$ & 0.116 & 0.419 \\
\hline $\begin{array}{l}\text { Life expectancy at } \\
\text { birth }(n=51)\end{array}$ & $\begin{array}{l}1.00 \\
(0.99- \\
1.00)\end{array}$ & 0.595 & 0.047 & 0.744 & $\begin{array}{l}1.00 \\
(1.00- \\
1.00)\end{array}$ & $<0.001$ & 0.135 & 0.346 \\
\hline $\begin{array}{l}\text { Expected years of } \\
\text { schooling }(n=51)\end{array}$ & $\begin{array}{l}1.00 \\
(1.00- \\
1.01)\end{array}$ & 0.024 & 0.186 & 0.192 & $\begin{array}{l}1.00 \\
(1.00- \\
1.00)\end{array}$ & $<0.001$ & 0.285 & 0.043 \\
\hline $\begin{array}{l}\text { Mean years of } \\
\text { schooling(n=51) }\end{array}$ & $\begin{array}{l}0.99 \\
(0.99- \\
1.00)\end{array}$ & 0.314 & -0.175 & 0.220 & $\begin{array}{l}0.99 \\
(0.99- \\
1.00)\end{array}$ & 0.209 & -0.149 & 0.297 \\
\hline $\operatorname{GNI}(n=51)$ & $\begin{array}{l}1.00 \\
(1.00- \\
1.00)\end{array}$ & 0.834 & -0.053 & 0.714 & $\begin{array}{l}1.00 \\
(1.00- \\
1.00)\end{array}$ & 0.018 & 0.067 & 0.639 \\
\hline IHDI(n=47) & $\begin{array}{l}0.98 \\
(0.94- \\
1.03)\end{array}$ & 0.655 & -0.086 & 0.567 & $\begin{array}{l}1.06 \\
(1.01- \\
1.12)\end{array}$ & 0.007 & 0.017 & 0.910 \\
\hline
\end{tabular}

\begin{tabular}{|c|c|c|c|c|c|c|c|}
\hline $\begin{array}{l}\text { Inequality adjusted life } \\
\text { expectancy } \\
\text { index(n=49) }\end{array}$ & $\begin{array}{l}0.99 \\
(0.96- \\
1.02)\end{array}$ & 0.783 & 0.059 & 0.687 & $\begin{array}{l}1.08 \\
(1.05- \\
1.12)\end{array}$ & $<0.001$ & 0.161 \\
\hline
\end{tabular}

\begin{tabular}{|c|c|c|c|c|c|c|c|}
\hline $\begin{array}{l}\text { Inequality adjusted } \\
\text { education index }(n=50)\end{array}$ & $\begin{array}{l}1.00 \\
(0.97- \\
1.03)\end{array}$ & 0.916 & -0.061 & 0.673 & $\begin{array}{l}1.00 \\
(0.97- \\
1.03)\end{array}$ & 0.776 & 0.007 \\
\hline
\end{tabular}

\begin{tabular}{|c|c|c|c|c|c|c|c|c|}
\hline $\begin{array}{l}\text { Inequality adjusted } \\
\text { income index }(n=45)\end{array}$ & $\begin{array}{l}0.99 \\
(0.94- \\
1.03)\end{array}$ & 0.726 & -0.047 & 0.754 & $\begin{array}{l}1.05 \\
(1.01- \\
1.09)\end{array}$ & 0.015 & 0.010 & $\begin{array}{l}0 . \\
946\end{array}$ \\
\hline GDI(n=49) & $\begin{array}{l}1.08 \\
(0.99- \\
1.18)\end{array}$ & 0.062 & -0.093 & 0.523 & $\begin{array}{l}1.02 \\
(0.87- \\
1.20)\end{array}$ & 0.747 & -0.019 & 0.897 \\
\hline $\mathrm{G} \|(n=49)$ & $\begin{array}{l}1.01 \\
(0.98- \\
1.03)\end{array}$ & 0.520 & -0.060 & 0.682 & $\begin{array}{l}0.94 \\
(0.92- \\
0.97)\end{array}$ & $<0.001$ & -0.179 & 0.220 \\
\hline HDI-Male(n=49) & $\begin{array}{l}1.16 \\
(1.11-\end{array}$ & $<0.001$ & 0.030 & 0.838 & $\begin{array}{l}1.11 \\
(1.06-\end{array}$ & $<0.001$ & 0.148 & 0.311 \\
\hline
\end{tabular}




\begin{tabular}{|c|c|c|c|c|c|c|c|c|}
\hline HDI- Female $(n=49)$ & $\begin{array}{l}1.03 \\
(0.98- \\
1.07)\end{array}$ & 0.184 & 0.011 & 0.939 & $\begin{array}{l}1.11 \\
(1.07- \\
1.15)\end{array}$ & $<0.001$ & 0.139 & 0.340 \\
\hline Gini Coefficient(n=46) & $\begin{array}{l}1.00 \\
(1.00- \\
1.00)\end{array}$ & $<0.001$ & 0.091 & 0.547 & $\begin{array}{l}1.00 \\
(1.00- \\
1.00)\end{array}$ & $<0.001$ & 0.087 & 0.564 \\
\hline
\end{tabular}


Table 1-C. Association of COVID-19 incidence and mortality with development indices in the African region

\begin{tabular}{|c|c|c|c|c|c|c|c|c|}
\hline \multirow[t]{2}{*}{ Variables } & \multicolumn{4}{|c|}{ Confirmed Case } & \multicolumn{4}{|c|}{ Confirmed Deaths } \\
\hline & $\begin{array}{l}\text { RR } \\
\text { (95\% } \\
\text { Cl) }\end{array}$ & $\begin{array}{l}\mathrm{P} \text { - } \\
\text { value }\end{array}$ & $\mathbf{r}_{\mathrm{s}}$ & $\begin{array}{l}\mathrm{P}- \\
\text { value }\end{array}$ & $\begin{array}{l}\text { RR } \\
\text { (95\% } \\
\text { Cl) }\end{array}$ & $\begin{array}{l}\mathrm{P} \text { - } \\
\text { value }\end{array}$ & $r_{s}$ & $\begin{array}{l}\mathrm{P}- \\
\text { value }\end{array}$ \\
\hline
\end{tabular}

AFRO

$\mathrm{HDI}(\mathrm{n}=46)$

1.11
$(1.08-$
$1.14)$

$<0.001 \quad 0.226$

0.131

1.11

$(1.08-$

$<0.001 \quad 0.057$

0.706

1.14)

1.13)

Life expectancy at

birth $(n=47)$

1.00

(1.00-

$0.152-0.020$

0.896

1.00

1.00)

(1.00-

0.069

1.00)

$\begin{array}{lllllllll}\text { Expected years of } & 1.00 & <0.001 & 0.046 & 0.759 & 1.00 & <0.001 & -0.109 & 0.466 \\ \text { schooling ( }(\mathbf{n = 4 7}) & (1.00- & & & & (1.00- & & & \\ & 1.00) & & & & 1.00) & & & \end{array}$

Mean years of
schooling( $n=46)$

$1.00<0.001 \quad 0.242$

0.105

1.00

(1.00-

1.00)

(1.00-

$<0.001$

0.110

0.467

1.00)

GNI(n=51)

1.00

$<0.001 \quad 0.206$

0.174

1.00

(1.00-

1.00)

1.00)

IHDI(n=42)

1.15

1.19)

$<0.001$

0.301

0.053

1.14

(1.10-

1.19)

Inequality adjusted

life expectancy

index $(n=47)$

1.05
$(1.02-$
$1.09)$

$<0.001 \quad 0.012$

0.939

1.06

(1.02-

1.09)

$\begin{array}{lllllllll}\text { Inequality adjusted } & 1.07 & <0.001 & 0.204 & 0.190 & 1.07 & <0.001 & 0.044 & 0.778 \\ \text { education } & (1.05- & & & & (1.05- & & & \\ \text { index(n=43) } & 1.09) & & & & 1.09) & & & \end{array}$

\begin{tabular}{|c|c|c|c|c|c|c|c|c|}
\hline $\begin{array}{l}\text { Inequality adjusted } \\
\text { income index(n=43) }\end{array}$ & $\begin{array}{l}0.98 \\
(0.95- \\
1.01)\end{array}$ & 0.281 & 0.150 & 0.337 & $\begin{array}{l}0.99 \\
(0.96- \\
1.01)\end{array}$ & 0.462 & 0.135 & 0.388 \\
\hline
\end{tabular}

\begin{tabular}{|c|c|c|c|c|c|c|c|c|}
\hline GDI(n=13) & $\begin{array}{l}1.11 \\
(0.99- \\
1.25)\end{array}$ & 0.064 & -0.292 & 0.334 & $\begin{array}{l}0.99 \\
(0.01- \\
84.95)\end{array}$ & 0.995 & -0.385 & 0.194 \\
\hline$G \|(n=13)$ & $\begin{array}{l}0.82 \\
(0.75- \\
0.89)\end{array}$ & $<0.001$ & -0.074 & 0.809 & $\begin{array}{l}0.287 \\
(0.08- \\
1.01)\end{array}$ & 0.053 & 0.058 & 0.851 \\
\hline HDI- Male(n=42) & $\begin{array}{l}1.13 \\
(1.09-\end{array}$ & $<0.001$ & 0.265 & 0.090 & $\begin{array}{l}1.12 \\
(1.09-\end{array}$ & $<0.001$ & 0.080 & 0.613 \\
\hline
\end{tabular}


1.16)

HDI- Female( $(n=42)$

1.08

(1.06-

1.11)

Gini Coefficient( $n=45)$
1.00

$(1.00-$

1.00)
1.16)

$\begin{array}{llll}1.07 & <0.001 & 0.031 & 0.844\end{array}$

(1.05-

1.09)

$\begin{array}{llll}1.00 & <0.001 & -0.123 & 0.422\end{array}$

(1.00-

1.00) 
Table 1-D. Association of COVID-19 incidence and mortality with development indices in the Western Pacific region

\begin{tabular}{|c|c|c|c|c|c|c|c|c|}
\hline \multirow[t]{2}{*}{ Variables } & \multicolumn{4}{|c|}{ Confirmed Case } & \multicolumn{4}{|c|}{ Confirmed Deaths } \\
\hline & $\begin{array}{l}\text { RR } \\
\text { (95\% } \\
\text { Cl) }\end{array}$ & $\begin{array}{l}\mathrm{P}- \\
\text { value }\end{array}$ & $r_{s}$ & $\begin{array}{l}\mathrm{P} \text { - } \\
\text { value }\end{array}$ & $\begin{array}{l}\text { RR } \\
\text { (95\% } \\
\text { Cl) }\end{array}$ & $\begin{array}{l}\mathrm{P} \text { - } \\
\text { value }\end{array}$ & $r_{s}$ & $\begin{array}{l}\mathrm{P} \text { - } \\
\text { value }\end{array}$ \\
\hline
\end{tabular}

WPRO

\begin{tabular}{|c|c|c|c|c|c|c|c|}
\hline $\operatorname{HDI}(n=14)$ & $\begin{array}{l}1.02 \\
(0.91- \\
1.16)\end{array}$ & 0.718 & 0.464 & 0.095 & $\begin{array}{l}0.99 \\
(0.91- \\
1.07)\end{array}$ & 0.818 & 0.466 \\
\hline
\end{tabular}

\begin{tabular}{|c|c|c|c|c|c|c|c|}
\hline $\begin{array}{l}\text { Life expectancy at birth } \\
(n=15)\end{array}$ & $\begin{array}{l}1.00 \\
(0.99- \\
1.00)\end{array}$ & 0.558 & 0.686 & 0.005 & $\begin{array}{l}1.00 \\
(0.99- \\
1.00)\end{array}$ & 0.247 & 0.660 \\
\hline
\end{tabular}

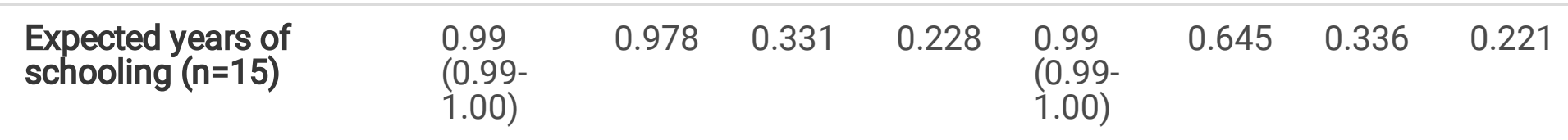

\begin{tabular}{|c|c|c|c|c|c|c|c|c|}
\hline $\begin{array}{l}\text { Mean years of } \\
\text { schooling }(n=15)\end{array}$ & $\begin{array}{l}0.99 \\
(0.90- \\
1.09)\end{array}$ & 0.937 & 0.406 & 0.133 & $\begin{array}{l}1.00 \\
(0.99- \\
1.00)\end{array}$ & 0.761 & 0.390 & 0.151 \\
\hline GNI(n=15) & $\begin{array}{l}1.00 \\
(1.00- \\
1.00)\end{array}$ & 0.915 & 0.429 & 0.111 & $\begin{array}{l}1.00 \\
(1.00- \\
1.00)\end{array}$ & 0.017 & 0.437 & 0.103 \\
\hline
\end{tabular}

\begin{tabular}{|c|c|c|c|c|c|c|c|}
\hline IHDI(n=11) & $\begin{array}{l}0.69 \\
(0.11- \\
4.36)\end{array}$ & 0.699 & 0.545 & 0.083 & $\begin{array}{l}0.98 \\
(0.93- \\
1.04)\end{array}$ & 0.628 & 0.486 \\
\hline
\end{tabular}

\begin{tabular}{|c|c|c|c|c|c|c|c|}
\hline $\begin{array}{l}\text { Inequality adjusted life } \\
\text { expectancy index }(n=15)\end{array}$ & $\begin{array}{l}1.02 \\
(0.94- \\
1.11)\end{array}$ & 0.598 & 0.670 & 0.006 & $\begin{array}{l}1.03 \\
(0.97- \\
1.08)\end{array}$ & 0.267 & 0.648 \\
\hline
\end{tabular}

\begin{tabular}{|c|c|c|c|c|c|c|c|c|}
\hline $\begin{array}{l}\text { Inequality adjusted } \\
\text { education index }(n=13)\end{array}$ & $\begin{array}{l}1.05 \\
(0.98- \\
1.12)\end{array}$ & 0.140 & 0.511 & 0.074 & $\begin{array}{l}1.01 \\
(0.95- \\
1.07)\end{array}$ & 0.624 & 0.420 & 0.153 \\
\hline
\end{tabular}

\begin{tabular}{|c|c|c|c|c|c|c|c|c|}
\hline $\begin{array}{l}\text { Inequality adjusted } \\
\text { income index }(n=11)\end{array}$ & $\begin{array}{l}0.99 \\
(0.95- \\
1.03)\end{array}$ & 0.710 & 0.345 & 0.298 & $\begin{array}{l}0.97 \\
(0.93- \\
1.02)\end{array}$ & 0.293 & 0.303 & 0.365 \\
\hline GDI(n=13) & $\begin{array}{l}1.30 \\
(1.01- \\
1.67)\end{array}$ & 0.035 & 0.242 & 0.426 & $\begin{array}{l}1.06 \\
(0.80- \\
1.42)\end{array}$ & 0.650 & 0.116 & 0.706 \\
\hline$G \|(n=13)$ & $\begin{array}{l}1.00 \\
(0.94- \\
1.07)\end{array}$ & 0.863 & -0.467 & 0.108 & $\begin{array}{l}0.99 \\
(0.95- \\
1.03)\end{array}$ & 0.814 & -0.443 & 0.130 \\
\hline
\end{tabular}




\begin{tabular}{|c|c|c|c|c|c|c|c|c|}
\hline HDI-Male(n=13) & $\begin{array}{l}0.99 \\
(0.91- \\
1.11)\end{array}$ & 0.998 & 0.407 & 0.168 & $\begin{array}{l}0.97 \\
(0.91- \\
1.03)\end{array}$ & 0.428 & 0.381 & 0.199 \\
\hline HDI- Female $(n=13)$ & $\begin{array}{l}1.01 \\
(0.91- \\
1.12)\end{array}$ & 0.864 & 0.385 & 0.194 & $\begin{array}{l}0.97 \\
(0.90- \\
1.04)\end{array}$ & 0.422 & 0.315 & 0.295 \\
\hline Gini Coefficient(n=11) & $\begin{array}{l}1.01 \\
(0.95- \\
1.07)\end{array}$ & 0.737 & 0.009 & 0.979 & $\begin{array}{l}1.00 \\
(1.00- \\
1.00)\end{array}$ & 0.114 & 0.050 & 0.884 \\
\hline
\end{tabular}


Table 1-E. Association of COVID-19 incidence and mortality with development indices in the SouthEast Asia region

\begin{tabular}{|c|c|c|c|c|c|c|c|c|}
\hline \multirow[t]{2}{*}{ Variables } & \multicolumn{4}{|c|}{ Confirmed Case } & \multicolumn{4}{|c|}{ Confirmed Deaths } \\
\hline & $\begin{array}{l}\mathrm{RR}(95 \% \\
\mathrm{Cl})\end{array}$ & $\begin{array}{l}\text { P- } \\
\text { value }\end{array}$ & $r_{s}$ & $\begin{array}{l}\mathrm{P}- \\
\text { value }\end{array}$ & $\begin{array}{l}\text { RR } \\
\text { (95\% } \\
\text { Cl) }\end{array}$ & $\begin{array}{l}\mathrm{P} \text { - } \\
\text { value }\end{array}$ & $r_{s}$ & $\begin{array}{l}\mathrm{P} \text { - } \\
\text { value }\end{array}$ \\
\hline
\end{tabular}

SEARO

\begin{tabular}{|c|c|c|c|c|c|c|c|}
\hline $\mathrm{HDI}(n=10)$ & $\begin{array}{l}0.76 \\
(0.52- \\
1.13)\end{array}$ & 0.173 & -0.006 & 0.987 & $\begin{array}{l}0.82 \\
(0.46- \\
1.44)\end{array}$ & 0.485 & 0.061 \\
\hline
\end{tabular}

\begin{tabular}{|c|c|c|c|c|c|c|c|}
\hline $\begin{array}{l}\text { Life expectancy at } \\
\text { birth }(n=10)\end{array}$ & $\begin{array}{l}0.99 \\
(0.99- \\
0.99)\end{array}$ & 0.002 & 0.188 & 0.602 & $\begin{array}{l}0.98 \\
(0.96- \\
1.00)\end{array}$ & 0.064 & 0.137 \\
\hline
\end{tabular}

\begin{tabular}{|c|c|c|c|c|c|c|c|c|}
\hline $\begin{array}{l}\text { Expected years of } \\
\text { schooling }(n=10)\end{array}$ & $\begin{array}{l}0.98 \\
(0.96- \\
1.02)\end{array}$ & 0.346 & -0.018 & 0.960 & $\begin{array}{l}0.99 \\
(0.94- \\
1.03)\end{array}$ & 0.630 & 0.155 & 0.668 \\
\hline
\end{tabular}

\begin{tabular}{|c|c|c|c|c|c|c|c|}
\hline $\begin{array}{l}\text { Mean years of } \\
\text { schooling }(n=10)\end{array}$ & $\begin{array}{l}1.01 \\
(0.98- \\
1.04)\end{array}$ & 0.497 & 0.406 & 0.244 & $\begin{array}{l}1.02 \\
(0.98- \\
1.06)\end{array}$ & 0.345 & 0.474 \\
\hline
\end{tabular}

\begin{tabular}{|c|c|c|c|c|c|c|c|}
\hline GNI $(n=10)$ & $\begin{array}{l}0.99 \\
(0.99- \\
0.99)\end{array}$ & 0.039 & -0.236 & 0.511 & $\begin{array}{l}0.99 \\
(0.99- \\
1.00)\end{array}$ & 0.251 & -0.170 \\
\hline
\end{tabular}

\begin{tabular}{|c|c|c|c|c|c|c|c|c|}
\hline IHDI $(n=10)$ & $\begin{array}{l}0.81(0.66- \\
1.004)\end{array}$ & 0.055 & 0.207 & 0.567 & $\begin{array}{l}0.85 \\
(0.63- \\
1.15)\end{array}$ & 0.300 & 0.268 & 0.454 \\
\hline
\end{tabular}

\begin{tabular}{|c|c|c|c|c|c|c|c|}
\hline $\begin{array}{l}\text { Inequality adjusted } \\
\text { life expectancy } \\
\text { index }(n=10)\end{array}$ & $\begin{array}{l}0.81 \\
(0.71- \\
0.91)\end{array}$ & 0.001 & 0.200 & 0.580 & $\begin{array}{l}0.75 \\
(0.70 \\
0.81)\end{array}$ & $<0.001$ & 0.170 \\
\hline
\end{tabular}

$\begin{array}{lllllllll}\text { Inequality adjusted } & 0.89 & 0.104 & 0.297 & 0.405 & \begin{array}{l}0.92 \\ (0.75-\end{array} & 0.409 & 0.377 & 0.283 \\ \text { education index } & \begin{array}{l}0.77- \\ (n=10)\end{array} & & & & \\ 1.02) & & & & & & \end{array}$

\begin{tabular}{|c|c|c|c|c|c|c|c|c|}
\hline $\begin{array}{l}\text { Inequality adjusted } \\
\text { income index } \\
(n=10)\end{array}$ & $\begin{array}{l}0.76 \\
(0.40- \\
1.43)\end{array}$ & 0.388 & -0.261 & 0.467 & $\begin{array}{l}0.87 \\
(0.40- \\
1.85)\end{array}$ & 0.721 & -0.116 & 0.751 \\
\hline GDI(n=9) & $\begin{array}{l}0.24 \\
(0.03- \\
1.60)\end{array}$ & 0.143 & -0.233 & 0.546 & $\begin{array}{l}0.70 \\
(0.60- \\
0.81)\end{array}$ & $<0.001$ & -0.151 & 0.699 \\
\hline
\end{tabular}

\begin{tabular}{|c|c|c|c|c|c|c|c|c|}
\hline$G \|(n=8)$ & $\begin{array}{l}1.53 \\
(1.36- \\
1.71)\end{array}$ & $<0.001$ & 0.429 & 0.289 & $\begin{array}{l}1.68 \\
(1.46- \\
1.94)\end{array}$ & $<0.001$ & 0.381 & 0.352 \\
\hline Male-HDI $(n=10)$ & 1.05 & 0.894 & 0.042 & 0.907 & 1.17 & 0.713 & 0.109 & 0.763 \\
\hline
\end{tabular}




\begin{tabular}{|c|c|c|c|c|c|c|c|c|}
\hline & $\begin{array}{l}(0.50- \\
2.17)\end{array}$ & & & & $\begin{array}{l}(0.50- \\
2.73)\end{array}$ & & & \\
\hline Female-HDI $(n=8)$ & $\begin{array}{l}0.78 \\
(0.62- \\
0.99)\end{array}$ & 0.044 & -0.190 & 0.651 & $\begin{array}{l}0.83 \\
(0.60- \\
1.14)\end{array}$ & 0.258 & -0.143 & 0.736 \\
\hline $\begin{array}{l}\text { Gini Coefficient } \\
(n=10)\end{array}$ & $\begin{array}{l}0.99 \\
(0.98- \\
1.01)\end{array}$ & 0.720 & -0.109 & 0.763 & $\begin{array}{l}0.99 \\
(0.98- \\
1.01)\end{array}$ & 0.958 & -0.122 & 0.737 \\
\hline
\end{tabular}


Table 1-F. Association of COVID-19 incidence and mortality with development indices in the Eastern Mediterranean region

\begin{tabular}{|c|c|c|c|c|c|c|c|c|}
\hline \multirow[t]{2}{*}{ Variables } & \multicolumn{4}{|c|}{ Confirmed Case } & \multicolumn{4}{|c|}{ Confirmed Deaths } \\
\hline & $\begin{array}{l}\text { RR } \\
\text { (95\% } \\
\text { Cl) }\end{array}$ & $\begin{array}{l}\text { P- } \\
\text { value }\end{array}$ & $r_{s}$ & $\begin{array}{l}\mathrm{P} \text { - } \\
\text { value }\end{array}$ & $\begin{array}{l}\text { RR } \\
\text { (95\% } \\
\text { Cl) }\end{array}$ & $\begin{array}{l}\mathrm{P} \text { - } \\
\text { value }\end{array}$ & $r_{s}$ & $\begin{array}{l}\mathrm{P}- \\
\text { value }\end{array}$ \\
\hline
\end{tabular}

EMRO

\begin{tabular}{|c|c|c|c|c|c|c|c|c|}
\hline HDI $(n=19)$ & $\begin{array}{l}1.03 \\
(0.99- \\
1.07)\end{array}$ & 0.117 & 0.386 & 0.103 & $\begin{array}{l}1.02 \\
(0.98- \\
1.06)\end{array}$ & 0.208 & -0.119 & 0.627 \\
\hline $\begin{array}{l}\text { Life expectancy at birth } \\
(n=21)\end{array}$ & $\begin{array}{l}1.00 \\
(1.00- \\
1.00)\end{array}$ & 0.125 & 0.299 & 0.189 & $\begin{array}{l}1.00 \\
(0.99- \\
1.00)\end{array}$ & 0.359 & -0.105 & 0.649 \\
\hline $\begin{array}{l}\text { Expected years of } \\
\text { schooling }(n=21)\end{array}$ & $\begin{array}{l}1.00 \\
(1.00- \\
1.00)\end{array}$ & 0.062 & 0.356 & 0.113 & $\begin{array}{l}1.00 \\
(1.00- \\
1.00)\end{array}$ & 0.086 & 0.099 & 0.668 \\
\hline $\begin{array}{l}\text { Mean years of } \\
\text { schooling }(n=20)\end{array}$ & $\begin{array}{l}1.00 \\
(1.00- \\
1.00)\end{array}$ & 0.350 & 0.374 & 0.104 & $\begin{array}{l}1.00 \\
(1.00- \\
1.00)\end{array}$ & 0.600 & -0.053 & 0.825 \\
\hline GNI(n=20) & $\begin{array}{l}1.00 \\
(1.00- \\
1.00)\end{array}$ & 0.248 & 0.585 & 0.007 & $\begin{array}{l}1.00 \\
(1.00- \\
1.00)\end{array}$ & 0.055 & 0.093 & 0.696 \\
\hline IHDI(n=8) & $\begin{array}{l}1.01 \\
(0.96- \\
1.06)\end{array}$ & 0.685 & -0.048 & 0.911 & $\begin{array}{l}1.02 \\
(0.97- \\
1.08)\end{array}$ & 0.320 & -0.167 & 0.693 \\
\hline
\end{tabular}

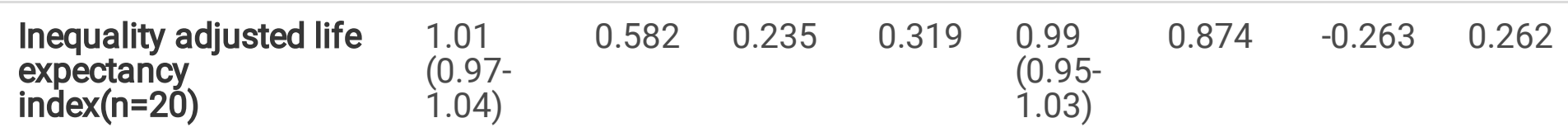

\begin{tabular}{|c|c|c|c|c|c|c|c|}
\hline $\begin{array}{l}\text { Inequality adjusted } \\
\text { education index }(n=16)\end{array}$ & $\begin{array}{l}1.01 \\
(0.99- \\
1.04)\end{array}$ & 0.225 & 0.418 & 0.107 & $\begin{array}{l}1.01 \\
(0.99- \\
1.04)\end{array}$ & 0.240 & -0.106 \\
\hline
\end{tabular}

\begin{tabular}{|c|c|c|c|c|c|c|c|}
\hline $\begin{array}{l}\text { Inequality adjusted } \\
\text { income index }(n=11)\end{array}$ & $\begin{array}{l}1.08 \\
(1.01- \\
1.16)\end{array}$ & 0.017 & 0.391 & 0.235 & $\begin{array}{l}1.07 \\
(1.01- \\
1.13)\end{array}$ & 0.018 & 0.273 \\
\hline
\end{tabular}

\begin{tabular}{|c|c|c|c|c|c|c|c|}
\hline GDI(n=14) & $\begin{array}{l}0.97 \\
(0.90- \\
1.04)\end{array}$ & 0.406 & -0.064 & 0.829 & $\begin{array}{l}0.83 \\
(0.76- \\
0.90)\end{array}$ & $<0.001$ & -0.332 \\
\hline
\end{tabular}

\begin{tabular}{|c|c|c|c|c|c|c|c|c|}
\hline$G \|(n=14)$ & $\begin{array}{l}1.01 \\
(0.97- \\
1.05)\end{array}$ & 0.406 & 0.187 & 0.522 & $\begin{array}{l}1.07 \\
(1.04- \\
1.12)\end{array}$ & $<0.001$ & 0.416 & 0.139 \\
\hline HDI- Male(n=19) & $\begin{array}{l}1.04 \\
(1.00-\end{array}$ & 0.032 & 0.465 & 0.045 & $\begin{array}{l}1.03 \\
(0.98-\end{array}$ & 0.139 & -0.075 & 0.759 \\
\hline
\end{tabular}




\begin{tabular}{|c|c|c|c|c|c|c|c|c|}
\hline & 1.09) & & & & $1.07)$ & & & \\
\hline HDI- Female $(n=19)$ & $\begin{array}{l}1.02 \\
(0.99- \\
1.05)\end{array}$ & 0.149 & 0.376 & 0.113 & $\begin{array}{l}1.00 \\
(0.97- \\
1.04)\end{array}$ & 0.725 & -0.215 & 0.377 \\
\hline Gini Coefficient $(n=11)$ & $\begin{array}{l}1.00 \\
(0.99- \\
1.00)\end{array}$ & 0.944 & -0.105 & 0.759 & $\begin{array}{l}1.00 \\
(0.99- \\
1.00)\end{array}$ & 0.433 & -0.146 & 0.669 \\
\hline
\end{tabular}

